This item was submitted to Loughborough's Research Repository by the author.

Items in Figshare are protected by copyright, with all rights reserved, unless otherwise indicated.

\title{
Election unspun? The mediation of the campaign
}

PLEASE CITE THE PUBLISHED VERSION

PUBLISHER

(C) Palgrave Macmillan

LICENCE

CC BY-NC-ND 4.0

REPOSITORY RECORD

Deacon, David, and Dominic Wring. 2019. "Election Unspun? the Mediation of the Campaign". figshare. https://hdl.handle.net/2134/2144. 
This item was submitted to Loughborough's Institutional Repository by the author and is made available under the following Creative Commons Licence conditions.

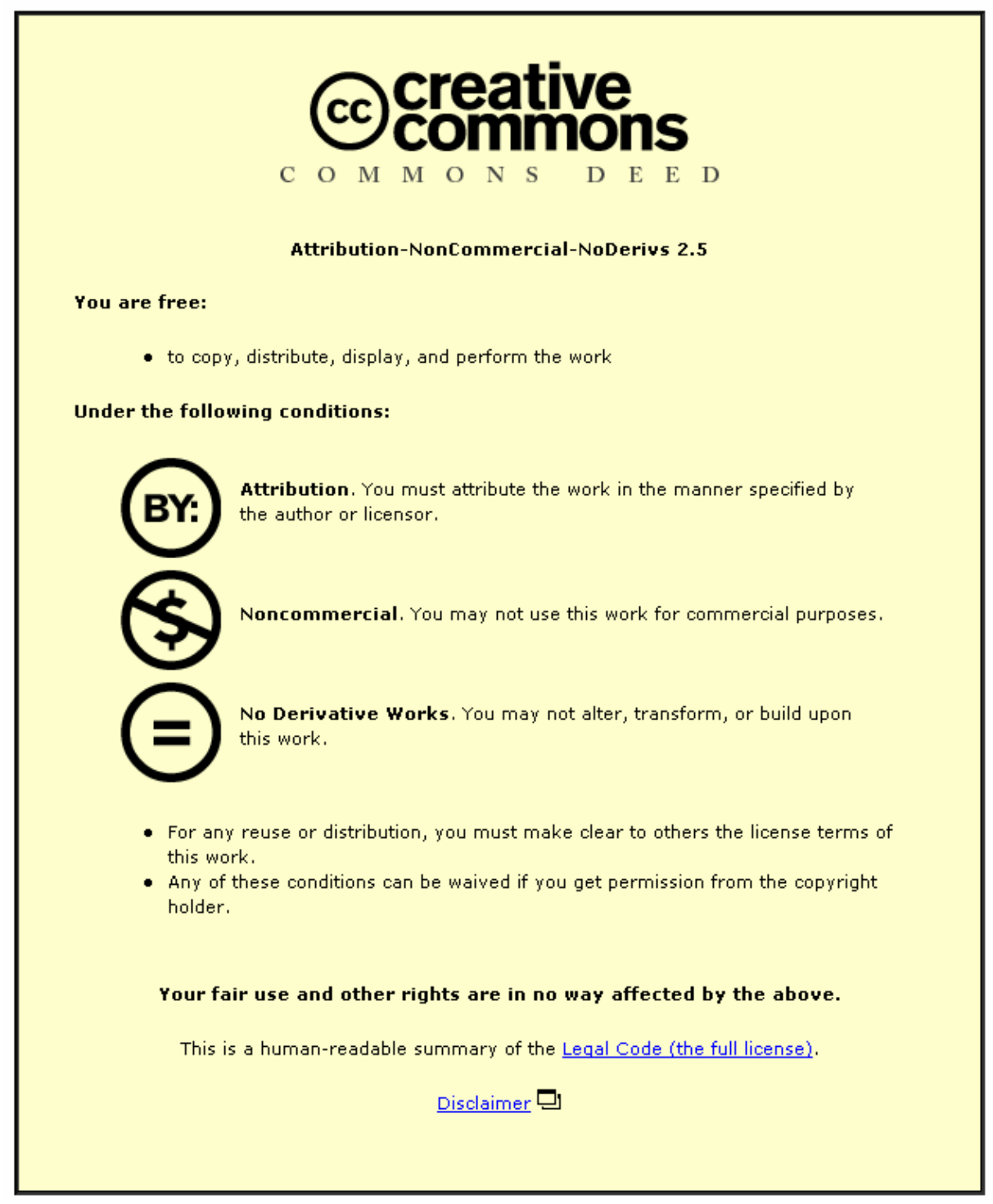

For the full text of this licence, please go to: http://creativecommons.org/licenses/by-nc-nd/2.5/ 
Deacon, D. and Wring, D. (2005) 'Election Unspun? The Mediation of the Campaign', in Geddes, A. and Tonge, J. (eds.) Britain Decides, Hampshire, Palgrave.

\section{Introduction}

Culture Secretary Tess Jowell spoke for many politicians when she complained that the 2005 general election was really about two distinct campaigns. The combatants in the second, less obvious case were not the two main rival parties but the candidates fighting to secure support and the journalists seeking to report their efforts. Jowell adhered to a widespread view that there were distinctive 'air' and 'ground' wars taking place and that the latter was an arguably more critical dimension in an election that had long been interpreted as an effort to encourage people just to vote following the marked fallout in participation last time. Politicians and journalists combined efforts to get public attention and even their endorsements would be challenged in various ways. The most obvious one were the multitude of rival stories that vied for the news agenda including major happenings like the death, burial and selection of a new Pope as well as the long expected marriage between the Prince of Wales and his partner Camilla Parker-Bowles. Allied to this, dramatic events such as the announcement of MG Rover cars' impending collapse and the vicious, seemingly unprovoked attack on a young mother also deflected attention from politics and elections. Arguably though it 
was the combined dominance of celebrity and lifestyle culture, particularly but not exclusively in the popular redtop newspapers, that underlined that the election and those fighting it would have to fight even harder to be seen and heard in a favourable light. It is then perhaps not surprising that one of the most effective media driven political interventions during the last parliament was from the television chef Jamie Oliver's Channel 4 sponsored crusade to change the poor quality of food served to the nation's school children. Such populist interventions and their celebrity style informality would also be a marked feature of the 2005 campaign.

\section{The 'Phoney' War}

Since at least 1992 and on some occasions before then, British general elections have been preceded by a 'phoney' or pre-election in which major politicians have come to increasingly rely on image consultants, spin doctors and other presentational experts to promote their case. The degree to which this is happening has led many to argue politics is in the grip of a permanent campaign but whilst this may have been the case in the first Labour term, the Iraq invasion seriously hampered attempts by the government to manage the news agenda during the second. ${ }^{1}$ Iraq harmed Tony Blair's public image and brought into question his trustworthiness on this and a whole range of issues. In approaching the 2005 campaign Blair and his strategists attempted to seize back the initiative by launching a so-called 'masochism' strategy that centred on him appearing in a variety of broadcast formats in an attempt to win back the confidence of those voters he had previously alienated. The Prime 
Minister did so in the knowledge his incumbency and media abilities appeared to give him a distinct advantage over his rivals Charles Kennedy and more especially Michael Howard.

The most significant event of the pre-campaign involved the three main party leaders as guests on their own individual day of Channel 5 programming. Although the appearances were not part of the formal election they were transmitted in February during a period research has suggested is crucial for many millions of people are making their decisions on how to vote. ${ }^{2}$ This factor was no doubt important in encouraging Tony Blair and his opponents to answer questions on special editions of the Channel's topical audience participation mid-morning Wright Stuff programme and an early evening debate presented by Kirsty Young. The later format led to sustained and robust questioning, primarily because the interrogation was restricted to half a dozen or so invited members of the public challenging the leaders who were able to explore, over the course of a few minutes, a topical issue of special relevance to them. Blair, for instance, was closely cross examined by a nurse who demanded whether he would work in the health service doing unpleasant but vital duties for comparatively poor pay. The directness of the questioner and her fellow female guests was picked up by the national press, but also noteworthy where the searching interventions from male participants on Iraq, tuition fees and education. Ultimately though the impact of these largely well executed interviews was overshadowed by the intervention of a woman heckler who tackled Blair with a specific complaint about the treatment of her son. The case, though picked up and used by the Conservatives, arguably 
reinforced Blair's message that he was prepared to listen to irate voters. Yet like much of the debate in the subsequent election, the more substantive exchanges between voters and politicians that had taken place on Channel 5 during the day were neglected in favour of reporting an unexpected event with a charismatic protagonist, compelling human interest dimension and/or good pictures.

The Prime Minster aided by an uncharacteristically low profile Alastair Campbell and David Hill, Campbell's successor at Downing Street, exploited his incumbency to an almost unprecedented degree in other ways. Aside from the masochism strategy Blair was a guest in a series of the less formal programmes he had long cultivated but which he now appeared on in a far more compressed space of time prior to his announcement of the election. These included a debate with an invited audience of young people on the popular Channel 4 Sunday lunchtime strand T4 in January before which a film of presenter June Sarpong shadowing the Prime Minister for a day was broadcast. Media commentators were cynical about Blair's intent but some viewers were evidently impressed by the Labour leader's candour as one first time elector later admitted when she admitted to supporting Labour on the strength of his 'fantastic' performance. ${ }^{3}$ Blair followed this with guest appearances on the GMTV breakfast show and 4's Richard and Judy in an effort designed to particularly appeal to the concerns and issues of so-called 'school gate mums' and their 'hard working families', key target audiences identified by pollsters and who both played a significant part in developing Labour's approach to this campaign. The Prime Minister even agreed to be 
the celebrity guest on the Channel 4 programme's 'You Say We Pay' interlude where he attempted to win a cash prize for a caller.

The Prime Minister's inability to answer many of the questions in the game show element of Richard and Judy programme demonstrated the potentially embarrassing consequences of his strategy, specifically that he was not as in touch with popular culture as he made out. ${ }^{4}$ Nevertheless his preparedness to court the kinds of mass audiences who increasingly avoided traditional current affairs programming led him to accept the invite to feature on ITV1's popular Saturday Night Takeway where presenters young Ant and Dec interviewed him in Downing Street in a discussion in which the junior protagonists made fun of him. This and the other appearances broke new ground and it would have been unthinkable for a serving Prime Minister to have contemplated allowing this particular form of access a generation ago for fear of the adverse public reaction. Now the response was likely to be more journalistic cynicism but this was ultimately of marginal importance to a politician when set against the opportunity to reach millions of undecided voters. Labour strategists also reasoned this kind of self-promotion played to strengths Blair's main rival Michael Howard did not possess. Howard responded with a photo-opportunity alongside his extended family and his wife made a number of interventions during the ensuing campaign, notably as a solo, if less than animated guest of the ITV1 lunchtime talk show 'Loose Women'. In 2001 her predecessor Ffion Hague had been curiously muted and rarely seen anywhere but by her husband's side. By contrast Cherie Booth played a more formal part of the Labour campaign by making a speech 
although the intervention against the anti-war Respect coalition attracted less mainstream comment than it might have done if she had attacked the Conservatives in the same way. Charles Kennedy and his wife Sarah received considerably more coverage following the arrival of their new baby son Donald during the opening stages of the campaign. The self-conscious appearance of so many family members in this way made offered a strikingly domesticated image in sharp contrast to the momentous events that had preceded the campaign and the bitterness of an election that was about to unfold.

\section{Broadcasting.}

In sharp contrast to 2001, Blair made a relatively low key announcement of the election date and immediately embarked on a helicopter trip to his party's most marginal seat in Dorset where he was greeted by the kind of photogenic crowd of invited supporters that would dominate most of his visits around the country. The only journalists who regularly made up his entourage came from the BBC, ITN, Sky and the Press Association because space was restricted to what were deemed to be the most important news media. Consequently a marked feature of the campaign was the way other excluded correspondents made a point of reporting their travels round Britain by helicopter, car, mobile home, scooter or even motorcycle sidecar in pursuit of Blair, other leading figures and floating voters. By doing this the politicians and media were endorsing an increasingly popular view that they needed to go beyond the 
confines of Westminster to reach out to the public and, more especially those who had abstained in the previous general election.

Party strategists increasingly recognised the importance of developing a rapport with local rather than just national media as a means of reaching voters as regional journalists were perceived as being more interested in the substantive issues and in touch with their audiences. Furthermore the lack of previous contact between local media and central government was likely to make for a more meaningful dialogue devoid of the cynicism or even sycophancy characteristic of the Westminster lobby. The controlled if somewhat suddenly announced regional visits to seats by different politicians meant there were relatively few meaningful encounters between electors and the elected. There were, however, some altercations between Michael Howard, John Prescott, Charles Kennedy and assorted hecklers, protestors and determined journalists like BBC2 Newsnight's Michael Crick and ITV1's Nick Robinson. Tony Blair avoided most of this courtesy of a very obvious security cordon and his party's carefully planned invitation only 'events', one of which did liven up when a Labour activist's daughter from Yorkshire accused Blair over his record in what had hitherto been another mundane visit.

The preponderance of public relations' 'pseudo events' involving leaders' encounters between politicians and their most loyal followers had a notable impact on other aspects of the campaign coverage. ${ }^{5}$ Protests from hecklers and cynical journalists aside, the relatively formulaic reporting of a succession 
of visits and soundbite driven speeches was a recurrent feature of news bulletins. By contrast the major live set piece debates hosted by the broadcasters involving the leaders during the latter stages of the campaign enabled members of the public to directly vent their frustrations. ITV1's Ask the Leader devoted separate editions to each of the main party leaders as well as the nationalist allies from Scotland and Wales. The session with Michael Howard involved a particularly tense exchange over the perceived centrality of immigration to the Conservative case and the charge that it was promoting racism. The equivalent BBC Question Time debate took the form of a single programme in which all three main leaders appeared in separate half hour slots. Blair was booed but Charles Kennedy appeared to come out of the encounter the least scathed, and seemed more at ease with his public interrogators than in his meeting with the feared BBC broadcaster Jeremy Paxman in the latter's series of televised interviews with each Prime Ministerial candidate. ${ }^{6} \quad$ Several commentators wrongly acclaimed the Question Time debate's apparent novelty (the same format had been used as early as 1983) as the next best thing to the much lobbied for live debate between the leaders. Despite assorted journalists demands for such a broadcast contest it is likely to be some time before a Prime Minister concedes to being directly cross-examined by his main opponents.

Most radio coverage of the general election was provided by the BBC. Local, regional and national stations all approached the campaign with a clear focus on their audiences' interests or, in some cases, the limits of their patience. Radio 4 catered for the more politically engaged with its flagship morning 
programme Today featuring in-depth analysis and characteristically direct questioning of leading politicians from presenter John Humphrys and his colleagues. Similarly the station's other main news coverage and features like Any Questions debate also devoted themselves over to the election. There was, however, one significant change from recent campaigns with the downgrading of Election Call, traditionally an agenda-setting morning coproduction with either $\mathrm{BBC} 1$ or 2 but which was now not simultaneously broadcast with either of them. Furthermore the audience phone-in programme was relegated to a slot after Radio 4's World at One and its loss of prominence confirmed when the Prime Minister declined to make a traditional appearance on its last edition. Blair also failed to play his intended part alongside his political rivals in UK Leaders Live, an independent radio network debate simultaneously broadcast across a range of affiliates.

Conscious of its demographic reach to younger people Blair was more accommodating of Radio 1's question and answer session than he had been with other stations. 1's innovative Newsbeat programme also carefully tailored its reporting of the campaign and provided additional information on a special website. Older audiences were also catered for with Jeremy Vine's show as it toured round the country providing the main focal point for Radio 2 coverage. The talk based Radio 5 Live inevitably devoted airtime to the election and the opinions of politicians and others including the actor and 'official' Labour supporter Kevin Whateley who called up the programme to make his case like any other member of the public. However the most unexpected intervention of this kind came prior to the formal campaign and 
involved Tony Blair making a surprise appearance on presenter Jono Coleman's final broadcast for London's Heart FM radio. A dumbfounded Coleman responded to the Prime Minister's praise by suggesting he was in fact impersonator Jon Culshaw; Blair's attempts to confirm his identity made it a surreal broadcast

If the politicians were given ample opportunity by broadcasters to promote themselves, these news media also attempted to assert their own agendas. For instance BBC's The Politics Show and presenter Andrew Neil's other strands together with BBC2 Newsnight and its Saturday special tried to offer their own particular take on event. Similarly concern with voter engagement led to the creation of ITV1's Ballot Box Jury and its interviews with floating voters whilst Newsnight's Student House performed a similar function, providing insights into how a largely undecided group of young people made up their minds over the course of the campaign. Sky News did this by concentrating on public concerns in the key marginal constituency of Darwen and Rossendale in Lancashire. Likeminded features formed the basis of the regional coverage provided by the $\mathrm{BBC}$ and ITV local news media and if this was not enough election watchers could also follow the campaign on the round the clock BBC 24, ITV, Sky and CNN news channels, some of which provided live broadcasts of the party's morning press conferences.

The rise of and debate over spin encouraged media inquisitiveness and interrogations of the various parties' well rehearsed claims; Channel 4 News 'Factcheck', ITV1 News 'Unspun' and other broadcast features consciously 
applied a technique popularised in American reporting of politics to subject candidates' statements, claims and the facts they based them on to expert scrutiny. 'Body language' specialists also appeared on at least three of the terrestrial networks to hold forth on what politicians' gestures could tell us about them and their motives. One appeared in a Channel 4 series of 'Election Unspun’ documentaries that also offered compelling insights into matters that were in danger of being neglected by the mainstream campaign. To this end BBC3 offered a quirky film about the history of heckling and had two trainees attempting but failing to unnerve various politicians at live events. They did, however, manage to aggravate the Conservative press office. Elsewhere BBC1's Panorama continued with its hard-hitting series of programmes on different social policies which, though not explicitly linked to election, were nevertheless of great relevance.

Table 1 lists the top ten themes covered by the national news media during the formal campaign (4 April - 6 May 2005). The dominant topic was the election process, a hybrid that covers the reporting of public opinion polls, party strategies, publicity initiatives and related themes. This is by no means a new phenomenon but it is noteworthy that the attention given the subject was even greater than in the last election when media and opposition criticism of 'spin' had become a recurrent feature of political debate. Here a particular concern was the apparent rise of voter disaffection and how this might be analysed and better understood. The second most prominent theme was impropriety, a theme analogous to sleaze, which appeared in 1997, and politicians' conduct (principally John Prescott punching a protestor) in 2001. 
But here the emphasis was on allegations relating to new rules that had encouraged a great increase in postal voting. Significantly a timely and highly critical statement by Richard Mawrey, the judge presiding over a fraud case in Birmingham involving Labour victors in the 2004 local elections intensified criticisms of the government. The Daily Mail was particularly vehement in attacking ministers and claimed the scale of postal balloting amounted to a 'corruption of democracy itself'.

\section{TABLE 1 ABOUT HERE}

Whilst the postal fraud issue seemed to favour the Conservatives' agenda the third theme 'Iraq' reinforced that of the Liberal Democrats. Though not a major aspect of the earlier stages of the campaign, the invasion became a key debating point later on with the leak and then publication of the controversial memo by Attorney General Lord Goldsmith on the legality of Blair's support for the US government's military action in the absence of UN sanction. Goldsmith's words were scrutinised and, more importantly, the wider issue revisited at arguably the most inopportune moment for Labour. The Prime Minister once again had his personal integrity called in to question by Michael Howard who labelled him a 'liar' and Charles Kennedy who once again criticised Blair's judgement. Where Iraq partly dominated the final full week of the campaign, the next placed item asylum and immigration had been more of an issue during the preceding fortnight. Media attention to the topic had been sustained by newspaper coverage of the issue going back some years and, more particularly, a controversial Express series of lead stories midway 
through the last parliament. The central claims that the government was failing to control immigration and that the asylum system was in chaos were given renewed impetus by the Conservatives' own focus on an issue where it enjoyed one of its few substantial leads in the polls over Labour. The conviction of illegal migrant Kamel Bourgass for the killing of a police officer gave the government's media and political critics another prime opportunity to raise the issue.

It was a telling feature of the election how few substantive policy issues arose and even where 'bread and butter' topics of major interest to voters were discussed, these debates tended to focus on particular case stories such as the outbreak of the hospital superbug, MRSA, or the case of a frustrated patient waiting for an operation to the detriment of wider discussion about other important aspects of NHS provision. Similarly Europe was marginalized as an issue as were other critical areas of public policy such as transport, Northern Ireland and housing.

\section{Newspapers}

Whilst British broadcasting and satellite remains heavily regulated by statute to guard against party political and other biased reporting, the so-called 'free press' are able to editorialise and slant news to suit their own varied perspectives. Audiences realise this and consistently place television and radio above the print media as a reliable source of information. This has not however prevented certain newspaper proprietors, editors and journalists from 
expressing forthright opinions, especially during election campaigns. Yet the agenda-setting 'Tory press' of the 1980s is no more and there has been a notable pattern of dealignment in recent years whereby titles have been more likely to publish criticisms of their favoured politicians or, perhaps more importantly, articles sympathetic about or even written by those whose views they oppose. Labour, or more particularly, its leader benefited from this trend in the 1990s and the personal focus on him rather than the party gave rise to the 'Tony press'. 7

\section{TABLE TWO ABOUT HERE}

Rupert Murdoch was a leading protagonist in creating the Tony press. His decision to switch the support of best selling Sun and its News of the World sister paper from Conservative to Labour became a major media talking point during the 1997 general election given the way these titles had mercilessly lambasted Blair's party before then. The endorsement was viewed as a preemptive act by Murdoch to protect his UK business interests from future government scrutiny. During the run-up to the 2005 election there was speculation as to whether the proprietor might order the Sun to switch its support from Labour, with the paper even arguing 'our mind has yet to be made up' near the beginning of the campaign although it was unequivocal about the Liberal Democrats who it is dismissed as a 'pathetic shambles'. Ultimately the likelihood of another Blair victory made the possibility of partisan change remote and the paper's prevarication limited any impact on the result it might have had. 
When the Sun finally declared for Labour it released red smoke from an office roof in a stunt resembling the recent announcement of the new Pope. The front page editorial 'One Last Chance' and others comments such as 'Blair still has a big job to do until his place in history is guaranteed' underlined the conditionality of its support for the government. There were also warnings that perennial Sun concerns such as crime, immigration and welfare needed to be addressed although the fiercely pro-war paper also mounted a strong defence of Blair after challenges to his trustworthiness in a debate over Iraq that intensified towards the end of the campaign. Just prior to polling day the Sun also managed to include an interview with 'Tony and Cherie' in which the couple were asked highly personal questions under the suggestive headline 'Why Size Matters'.

Overall the Sun, like a number of redtops and its News of the World sister, downplayed much of the election and preferred to lead on the type of celebrity driven items it felt were of more interest to its youthful readership. There were even attempts to combine the two stories with the launch of a get out the vote featuring various personalities including Americans like Britney Spear. The paper also emblazoned some its election coverage with three models in states of undress to represent the parties in a feature that had dominated the limited campaign reporting in the rival Star in 2001. The similarity is instructive because the latter newspaper is the only national title to have significantly gained in circulation terms since then; the Star is also the publication in Table 2 that had the least to say about the general election, an 
acknowledgement perhaps of the fact that a majority of its largely pro-Labour audience had not voted in 2001 and would not in 2005. Significantly and uniquely the Star was the only national newspaper to express no clear preference for or against any party.

Though owned by the same company as the Star, the Express titles offered a very clear message to their readers to endorse the Conservatives. The daily had been particularly vociferous in attacking Labour for having, in its view, neglected to take firmer action against illegal asylum seekers. This was to expected given the paper had retracted its support and returned to its traditional pro-Conservative position in 2004 following the accession of Michael Howard to the leadership. Ideological consistency, clearer leadership and commercial success made the paper's mid-market rival the Daily Mail a more formidable political force. It too pursued Labour on many issues but also made specific criticisms of Blair's own perceived failings as a leader. The Mail came out with a more emphatic statement in support of Howard than in 2001 when it had focused its entire editorial on attacking the government. Interestingly the slightly more liberal Mail on Sunday did the reverse by changing its pro-Conservative stance to one that remained stridently antiLabour but also acknowledged the Liberal Democrats as a party worthy of support.

The other most politically consistent newspaper is the Mirror which, for many years, was the only popular title to support Labour. Former editor Piers Morgan fierce denunciation of the Iraq invasion weakened the paper's 
standing within Downing Street and further deteriorated a relationship that had already been strained by the Prime Minister's courting of its bitter Sun rival with exclusive stories and favours. Morgan's departure improved the situation and, motivated by a concern that it needed to mobilise the overwhelmingly pro-Labour Mirror readership, Blair wrote a handwritten appeal for publication in the paper declaring: 'Only you can make sure Britain keeps going forward with Labour rather than back with the Tories'. Successive editorials, features and stories responded in kind by making the case for a third term alongside items on the Conservative threat. The polling day edition underlined the message with a graphic frontpage portrayal of Michael Howard as a vanquished vampire under the headline 'Vote Labour- there is too much a stake'. The Sunday Mirror and People followed a similar, though less engaged editorial line, mindful of the former's editor Tina Weaver view that front page political stories 'are nigh on commercial suicide- unless we're looking at the shenanigans of cabinet ministers'. ${ }^{8}$

Like the Mirror, the Guardian and latterly the Independent had been repositories of anti-Tory sentiments during the 1980s and had thus consolidated their reputations among left of centre readers. Their criticism of government did, however, not desist once Labour got elected and there were often tense exchanges over various issues, notably Iraq. Ministers often singled out the Guardian, the most popular newspaper with its party members, for particular criticism for the way it opposed many new initiatives. Yet the newspaper once again endorsed the government and in spite of the fiercely divergent opinions on the election expressed in its guest columns and 
letters' pages: denunciations of Blair were matched by an offer from journalist Polly Toynbee to send nose pegs to reluctant Labour voters in the hope of persuading them to the polls. Furthermore several front-page stories published during the campaign framed issues in a way that promoted the government's position. Sunday sister the Observer did likewise but there was no rapprochement between the Independent titles and a party they had both briefly endorsed in 1997. Motivated by a firmly anti-war position, both newspapers gave media representation to the upsurge in public sympathy for the Liberal Democrats. The Independent betrayed its sentiments during by devoting considerable coverage to the defection of former Labour MP Brian Sedgemore to the party and portrayed it as 'a signal moment' and symptomatic of a wider electoral trend apparent in the polls and confirmed on election day.

There was some speculation that the Telegraph newspapers might soften their attitudes or even support the government following their group's acquisition by the Barclay brothers. Various restructuring plans and editorial changes did not, however, result in a notable shift of political emphasis and both titles not only continued with their criticisms of Blair and his party but were some of the Conservative leadership's more fervent supporters. The Telegraph's traditional centre-right rival The Times continued with its position of supporting the government having closely aligned itself with Blair's foreign controversial policy decisions, notably over Iraq. It was an agenda shared by all of proprietor Rupert Murdoch's newspapers worldwide. Interestingly an article by Murdoch's economist Irwin Stelzer shortly before the campaign 
argued 'Why Brown is Wrong for No.10' and gave a strong hint that the businessman's patience with the government might not outlast Blair's departure.

The Times' finally declared its position on the election by arguing Labour should remain in office with a reduced majority, more Conservative representation and the defeat of a number of named left-wingers from the government backbenches. By contrast the Sunday Times, which has always boasted a different, more strident political if not partisan approach to its sister paper made successive attempts to embarrass the government with the publication of a leaked memo from Alastair Campbell to his fellow strategists and an even more sensitive civil servant document relating confidential advice authored prior to the invasion of Iraq. The newspaper also made the alarming claims that there were an estimated 500,000 illegal immigrants, approximately $1 \%$ of the population, currently in the UK. It was then of little surprise when the Sunday Times finally declared for the Conservatives reversing its albeit tepid support for Labour last time.

The Times and Financial Times support of Labour meant they were the only two papers that voted differently to their audiences' first choice party although it is worth noting that both were the only titles to have at least a significant minority of readers (20\% or more) voting for each of the three main candidates (Table 3). Even the Star declaration for no one was technically in line with its nominally pro-Labour followers because it was the only national with a majority of readers who did not vote in the general election, thereby 
extended a trend begun in 2001. The paper had in the past veered from Labour to Conservative and back again but its stance, a perhaps still surprisingly rare position for a national newspaper, reflected some understanding of the market for news and that the election did not appear to be a primary or even significant interest for most purchasers. Arguably the ability of the Star to counter the downward trend in circulation was linked to an aggressively celebrity driven product that consciously emulated and provided a daily equivalent of successful glossy weekly and monthly magazines like Heat and Take a Break. The Sun, by comparison, may be contemplating whether to continue with its relatively highly political and politicised coverage, especially with the post-election of its current affairs editor Trevor Kavanagh.

\section{TABLE THREE ABOUT HERE}

Aside from editorial changes to its news content the Sun may also be contemplating switching its partisan support back to the Conservatives in line with the steady although unspectacular rise in support for the party among its readership in this election. This is not to say the underlying right-wing ideological agenda of the paper is likely to change given it has remained largely in tact since Murdoch first imposed it a quarter of a Century ago. The other, most noteworthy swing amongst newspapers audiences replicated a wider shift of support to the Liberal Democrats that was contributed to, perhaps significantly in some seats, by the change of allegiance among those who read the titles most associated with Labour. The change among Mirror consumers was noticeable but made little difference to the overall pattern of 
support within the paper's constituency. More spectacular was the switch of Guardian readers which they were evenly divided between the two main antiConservative parties.

\section{Advertising and new media.}

The major parties enjoy a major advantage in terms of the overall exposure the news media give them when compared with their smaller rivals. This ability to generate publicity is of course a reflection of their electoral status and greater resources in the form of expertise and funding for advertisements. The election was, however, noteworthy for the way the Liberal Democrats were able to mount a major marketing campaign courtesy of $£ 2.4$ million from City financier Michael Brown, a huge donation and the largest given to a third party for some time. The grant enabled the party's advertising agency to buy space in newspapers, on billboards and on certain popular websites to promote a core message that challenged the assumption that a vote for them was a wasted one. Other copy focused on key policy issues including health and also featured celebrities who had switched allegiance from Labour such as Claire Rayner, Anita Roddick and former BBC Director General Greg Dyke. Leader Charles Kennedy, who was regarded as a major asset, appeared in many of the advertisements and also in several of the Party Election Broadcasts, the most memorable of which had a boy representing Tony Blair 'crying wolf' in an attack on the government for having supported the Iraqi

invasion based on a mistaken belief that weapons of mass destruction existed. 
The Conservatives re-hired the services of the Saatchi brothers' agency which was hardly surprising given one of them, Maurice, had previously been appointed Co-Party Chairman alongside the Shadow Cabinet member Liam Fox. Yet for all their experience it was widely believed that the main strategic acumen behind the Tories' campaign came from Lynton Crosby, an Australian political consultant who had played a major role in the supporting his native right-wing Liberal Party's successive election victories. The Conservative advertising did, however, resemble earlier Saatchi copy from previous campaigns because of the way the strong by-line 'Are You Thinking What We're Thinking' became one of the most memorable electoral messages. Most of the posters consisted of pointed questions which drew attention to apparent shortcomings of the Labour government such as its alleged failure to deal with illegal immigration, rising violent crime and dirty hospitals. These advertisements included highly suggestive messages to voters claiming it was not racist to mention asylum or how they would feel if their own daughter was attached by someone out on a government backed parole scheme. The Party Election Broadcasts conveyed a similar message although were slightly more upbeat. Leader Michael Howard was not widely regarded as a popular figure with the public although he had contributed to a revival in party morale following his installation. Consequently the presidential style of the campaign encouraged his strategists to devote a Broadcast to endorsing Howard with comments from his senior colleagues and thus in a way which that also promoted the team. 
Labour again used the services of the advertising agents TBWA, a firm managed by the high profile sympathiser Trevor Beattie. The agency's more memorable work did not appear through the usual channels but on the party's website prior to the beginning of the formal campaign. An unflattering image of Michael Howard and his Shadow Chancellor Oliver Letwin as flying pigs was intended as an attack on their economic policies and appeared as one of four possible designs to be used on a site which asked members to vote for their favourite. The copy and another depicting Howard as a manipulative sorcerer type figure were criticised for their allegedly anti-Semitic overtones given the politicians' Jewish ancestry. Labour denied the charge and quickly removed the offending items from the website but achieved the kind of exposure for its message that it never really achieved through its other, more 'official' advertising. The latter focused on promoting the government's role in sustaining economic growth and stability and suggested a vote for the Conservatives risked this. In addition the affiliated trade union Unison launched its own advertising campaign against Letwin's alleged plans to cut public spending by $£ 35$ billion.

Michael Howard appeared in other Labour advertisng, most notably a PEB designed to remind voters of his record as minister implicated in some of the Thatcher and Major governments' more controversial measures. This, other PEBs and most of the advertising stressed a controversial belief that the Conservatives might retake office by default involving the mass abstentions or defections to alternatives by Labour voters. The consequences of this were addressed in one Broadcast featuring loyal supporters extolling the virtues of 
the National Health Service and the party's role in its formation. The most striking PEB was, however, carefully directed and edited by Anthony Minghella, the Oscar winning director of The English Patient. Minghella's film centred on the relationship between its two featured protagonists, Tony Blair and Gordon Brown, and attempted to demonstrate that media stories of their allegedly deteriorating relationship was more speculative than real. The PEB did not convince some of the critics. 


\section{Conclusions}

The 2005 general election was noteworthy for the understated and in some cases limited coverage many news media organisations gave the campaign. Their approach was motivated by a number of factors, but none more so than a perception, reinforced by the dramatic fall in turnout in 2001, that a significant minority of their audience was not particularly interested in the election. In a highly competitive media market boasting hundreds of rival publications and channels vying for audience attention, producers of campaign related coverage gave considerable to thought as to how they might make their offerings more attractive and interesting to new and existing viewers, readers and listeners. Here there is a clear worry among the more commercially minded that any further loss of consumers could have a significant and detrimental effect on their profitability in terms of advertising revenues. This could lead to even more dramatic changes in coverage in the future, all predicated on a similar assumption, specifically that elections are boring and do not shift product or boost shareholders' profits. It will be interesting to see how certain news media, the Sun in particular, attempt to straddle their self-style roles of being in touch with popular opinion and also leading it. Britain's best selling daily continues to decline and with it may also its fortunes and influence.

Looking through the television schedules, radio programming and newspaper articles during the 2005 campaign it is striking how compartmentalised the election coverage was into certain pages or time slots and how easily avoidable it all was for many citizens, and especially the growing number with 
access to new media technologies and who could thus follow any of a myriad of interests. It is striking how in this election strategists tried to bypass the problem by placing their candidates and their family members into the widest range of media possible and in doing so probably spent as much time preparing candidates for appearances on talk shows and other supposedly 'soft' programming as they did for the major set piece interviews. Allied to this trend another commentator has noted how the parties are responding to audience desertion from the news media by seeking to more directly communicate their case to prospective supporters with 'more sophisticated messages (that) are being highly targeted and taking place out of sight of the mass media'. The 2005 general election may be remembered as the campaign when journalists and politicians finally awoke to the realities of living in a diverse, multi-channel age. Arguably some of the voters also did by switching off and turning over. 
Table 1: The Issue Agenda: Top 10 Themes in National Media Coverage ${ }^{9}$

\begin{tabular}{|c|c|c|c|c|}
\hline Theme & 2001 & $\begin{array}{l}\text { Prominenc } \\
\mathrm{e}\end{array}$ & 2005 & Prominence \\
\hline 1 & Labour & $39 \%$ & Electoral process & $44 \%$ \\
\hline 2 & Europe & $9 \%$ & Political impropriety & $8 \%$ \\
\hline 3 & Health & $6 \%$ & Iraq & $8 \%$ \\
\hline 4 & Politicians' conduct & $6 \%$ & $\begin{array}{l}\text { Asylum and } \\
\text { immigration }\end{array}$ & $7 \%$ \\
\hline 5 & Taxation & $6 \%$ & Taxation & $5 \%$ \\
\hline 6 & Crime & $4 \%$ & Health & $4 \%$ \\
\hline 7 & Education & $4 \%$ & Crime & $4 \%$ \\
\hline 8 & Public services & $4 \%$ & Economy & $4 \%$ \\
\hline 9 & Social security & $3 \%$ & Education & $3 \%$ \\
\hline 10 & Other & $19 \%$ & Other & $13 \%$ \\
\hline
\end{tabular}


Table 2: Declarations of National Newspapers $2001 \& 2005^{10}$

\begin{tabular}{|l|l|l|l|l|}
\hline & $\mathbf{2 0 0 1}$ & & $\mathbf{2 0 0 5}$ & \\
\hline Daily Press & & Circulation & & Circulation \\
\hline The Guardian & Labour & 0.40 & Labour & 0.34 \\
\hline The Independent & Anti-Cons & 0.23 & Lib Dem & 0.23 \\
\hline The Times & Labour & 0.71 & Labour & 0.65 \\
\hline The Telegraph & Conservative & 1.02 & Conservative & 0.87 \\
\hline The Financial Times & Labour & 0.49 & Labour & 0.38 \\
\hline The Daily Express & Labour & 0.96 & Conservative & 0.87 \\
\hline The Daily Mail & Anti-Labour & 2.40 & Conservative & 2.30 \\
\hline The Sun & Labour & 3.45 & Labour & 3.26 \\
\hline The Mirror & Labour & 2.79 & Labour & 2.29 \\
\hline The Star & Labour & 0.60 & No Preference & 0.85 \\
\hline Sunday Press & & & & \\
\hline The Observer & Labour & 0.45 & Labour & 0.42 \\
\hline $\begin{array}{l}\text { Independent } \\
\text { Sunday }\end{array}$ & Anti Labour & 0.25 & Lib Dem & 0.18 \\
\hline The Sunday Times & Labour & 1.37 & Conservative & 1.35 \\
\hline $\begin{array}{l}\text { The Sunday } \\
\text { Telegraph }\end{array}$ & Conservative & 0.79 & Conservative & 0.65 \\
\hline The Mail on Sunday & Conservative & 2.33 & Anti-Labour & 2.37 \\
\hline The Sunday Express & Labour & 0.90 & Conservative & 0.84 \\
\hline The Sunday Mirror & Labour & 1.87 & Labour & 1.53 \\
\hline $\begin{array}{l}\text { The News of the } \\
\text { World }\end{array}$ & Labour & 3.90 & Labour & 3.64 \\
\hline The People & Labour & 1.37 & Labour & 0.94 \\
\hline $\begin{array}{l}\text { Star on Sunday } \\
\text { N/A }\end{array}$ & $\mathrm{N} / \mathrm{A}$ & No preference & 0.46 \\
\hline
\end{tabular}


Table 3: Readership Allegiances of National Daily Newspapers 2001 \&

$2005^{11}$

\begin{tabular}{|l|l|l|l|l|}
\hline $\begin{array}{l}\text { Daily Press } \\
\text { Result }\end{array}$ & $\begin{array}{l}\text { Lab } \\
\mathbf{3 6}(\mathbf{4 2})\end{array}$ & $\begin{array}{l}\text { Cons } \\
\mathbf{3 3}(\mathbf{3 3})\end{array}$ & $\begin{array}{l}\text { LD } \\
\mathbf{2 3}(\mathbf{1 9})\end{array}$ & $\begin{array}{l}\text { (LD-Cons } \\
\mathbf{3 . 1}\end{array}$ \\
\hline The Guardian
\end{tabular}

${ }^{1}$ N.Ornstein and T.Mann, The Permanent Campaign and Its Future. Washington: AEI and Brookings Insititute, 2000

${ }^{2}$ W.Miller et al., How Voters Change, Oxford: Clarendon, 1990

${ }^{3}$ The Guardian $21^{\text {st }}$ April 2005.

${ }^{4}$ Marina Hyde, The Guardian $29^{\text {th }}$ April 2005.

${ }^{5}$ D.Boorstin, The Image. London: Weidenfeld \& Nicolson, 1961

${ }^{6}$ Philip Cowley, a fellow contributed to this volume, was present in the studio debate and recognised Blair suffered a disadvantage appearing last on the programme given the rising temperature in the auditorium caused by the heat of the lights not to mention the raised passions among those present in the audience.

'D. Wring, 'The Tony Press', in A.Geddes and J.Tonge, Labour's Second Landslide: the British General Election 2001, Manchester: Manchester University Press, 2001; D. Deacon and D. Wring, 'Partisan Dealignment and the British Press', in J. Bartle, I.Crewe and B.Gosschalk (eds) Political Communications: the British General Election of 2001, London: Frank Cass, 2002.

${ }^{8}$ The Observer, 24 $4^{\text {th }}$ April 2005.

${ }_{9}$ Loughborough University Communication Research Centre, The Guardian, $2^{\text {nd }}$ May 2005

${ }^{10}$ Figures from Audit Bureau of Circulation.

${ }^{11}$ R. Worcester, P. Baines and R. Mortimore, Explaining Labour's Landslip, London: Politicos, 2005. 